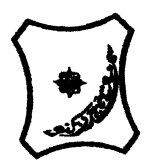

Bayero Journal of Pure and Applied Sciences, 12(2): 149 - 155

Received: November, 2019

Accepted: December, 2019

ISSN 2006 - 6996

\title{
CORRELAT1ON OF NOSOCOMIAL INFECTION WITH PROLONGED HOSPITAL STAY IN KANO NIGERIA
}

\author{
Alkali, B $^{{ }^{*}}$., Agwu, $E^{1}$., Sarkinfada, F $^{2}$, Idris, A. M $^{3}$. and Mada, S,B. ${ }^{4}$ \\ ${ }^{1}$ Department of Microbiology and Immunology, Faculty of Biomedical Science, Kampala International \\ Hospital Bushanyi, Uganda \\ ${ }^{2}$ Department of Health and Medical Sciences, Khawariszmi International College Abu Dhabi, United \\ Arab Emirate. \\ ${ }^{3}$ Department of Medical Microbiology and Parasitology, Faculty of Clinical Science, Bayero University \\ Kano, Nigeria \\ ${ }^{4}$ Department of Biochemistry, Ahmadu Bello University Zaria, Nigeria. \\ *Corresponding author: balkali2012@gmail.com; amikibiya@gmail.com +234 8035876964
}

\begin{abstract}
Nosocomial infections or Health Care-Associated Infections (HCAIs) occur due to prolonged hospital stay and has been implicated in antimicrobial resistance, and an increase in socio-economic disturbance, long term disability, and increased mortality rate. There is paucity information on the burden of HCAIs because of poorly developed surveillance systems and inexistent control methods. We aimed to investigate the prevalence of nosocomial infection due to prolonged hospital stay in selected tertiary hospitals of Kano metropolis. Retrospective data were collected from three hospitals with a total number of admitted patients and the number of prolonged hospital stays during the month of study. A total of 401 clinical samples collected from patients admitted for $\geq 14$ days and the age of $\geq 18$ years from all study sites. Examples include wound swabs, urine samples, urine catheters, and nasal intubation. All the samples were processed by the standard bacteriological laboratory procedure of the Clinical laboratory standard institute. The results showed that the percentage of prolonged hospital stay reveals that in Kano 40.34\%, Murtala Muhammad Specialist Hospital (MMSH) 50.54\% with the least at Muhammad Abdullahi Wase Specialist (MAWSH) 28.91\%. Age served as significant factors for acquired HCAIs; participants aged were 41 - 70 years have a higher prevalence of nosocomial infections. From 138 positive isolates observed, Murtala Muhammad Specialist Hospital (MMSH) has height nosocomial infection of $41.4 \%$, with the least Aminu Kano Teaching Hospital (AKTH) has 29\%. Among the Site of infection, $34.8 \%$ isolates were wounds Swabs (SSIs), urine (UTI) $31.2 \%$, and least was nasal intubation 11.6\%. Among pathogens isolated $E$. coli is the most prominent organism with $26.1 \%$ and the least Streptococcus pyogenes (7.9\%). This study showed that the prevalence of Prolong hospital stay in Kano was 40.34\%, AKTH 39.53\%, MMSH50.50\%, and MAWSH $28.91 \%$. The prevalence of nosocomial infection was 34.3\%. Gram-negative bacteria were the predominant isolates.

Keywords: Nosocomial infection, Prolonged Hospitals Stays, Antimicrobial Resistance, Gram-negative bacteria.
\end{abstract}

\section{INTRODUCTION}

Nosocomial infections or Health Care-Associated Infections (HCAIs) is one of the significant global Public health problems for both patients and health care professionals (Pitte et al., 2011; Iliya et al., 2019). These infections developed by patients while in a health care facility due to the introduction of endogenous or exogenous pathogens from other patients or contaminated Invasive devices. The disease may or may not expressed during the hospital stay (Wohrley et al., 2019). The infection occurring 48 hours after admission, three days of discharge or 30 days of operation are usually considered healthcareassociated infections (Haque et al, 2018). Additionally, they comprise occupational infections among the medical staff (WHO, 2016). Invasive devices such as catheters and ventilators employed in modern health care are associated with these infections, of every hundred hospitalized patients, seven in developed and ten in developing countries can acquire one of the healthcare-associated infections (Khan et al., 2017). 
Patients in Intensive Care Units (ICUs), burn units, and those undergoing operation surgeries are populations that are at high risk. According to the Extended Prevalence of Infection in Intensive Care (EPIC II) study, the proportions of infected patients within the ICUs are often as high as 51\% (Wang et al., 2019).

Presently, nosocomial infections have developed one of Africa's immense task, what is even more frightening is the detection of both emerging and re-emerging multidrug-resistant strains of infectious organisms in the hospitals, which has additional compact the efficacy of the existing therapy and care with related lethal consequences (Khan et al., 2017). Most developed countries of the world have surveillance systems that give steady information on national trends of endemic Hospital-associated infections, such as the German hospital infection (Khan et al., 2017).

For instance, while getting care for other diseases, many patients probably get respiratory infections and make it becomes troublesome to spot the prevalence of any nosocomial infection in the continuation of primary care (Prashanath, 2019). These infections get noticed only when they become an epidemic. Yet, there is no institution or a country that may claim to have resolved this endemic problem (WHO, 2016).

The occurrence of HCAIs is already significant in developed countries, where it upsets from $5 \%$ to $15 \%$ among hospitalized patients and as high as $50 \%$ in ICU (Alormenyo et al., 2013) In developing countries is somehow higher with $19 \%$ prevalence of HCAIs among hospitalized patients (WHO, 2016; Iliyasu et al., 2016). In the hospital environment, Health CareAssociated Pathogen scan colonizes the respiratory, urinary, gastrointestinal tract, and wounds of the patients and those of mechanically ventilated life support. It shows a particular predilection for the ICU, and causes prolonged hospital stay, challenges faced by healthcare stakeholders Review this sentence (Marriott et al., 2019). It is essential to recognize bases and modes of spread of infection and to implement records focused on hindrance guide-lines and practices (Chandra et al., 2015).

In Kano State, Northwest Nigeria, there is scarce data that showed possible risk factors that can course HCAIs, which result from prolonging hospital stay by the related patients. It is not clear why hospitals delay discharging patients with soft tissue infections? Or why and how long patients remain in the hospital after their disease conditions have been diagnosed? It is not yet clear whether the issues associated with the known delay before the hospital discharges patients, patients, staff, facility, or communityrelated? If the cause of delay is related to microbial characteristics, It is not clear also if the delay in treating identified pathogens is due to resistance or re-infection, or patient's noncompliance to the prescribed regimen, the issue of quality of drugs available in any country per unit time.

\section{MATERIALS AND METHODS \\ Study Area}

The study was conducted at the Kano metropolis of North-west Nigeria. Kano State is located in the Northwest geopolitical zone of Nigeria. It comprises of 44 Local Government Area with an estimated population of over 13 million and $20,760 \mathrm{sq} \mathrm{km}$ in area national Bureau of Statistics (NBS, 2018). It lies between latitudes $10 \mathrm{o} 33 \mathrm{~N}$ to $11015 \mathrm{~N}$ and longitudes $34 \mathrm{oCE}$ to 80 20CE (NBS, 2018).

\section{Ethical Permission}

The study was approved by, Health service management board Kano(HMB/GEN/488/VOL.1,16th FEB 2016), Ministry of Health Kano state(REF/OFF/797/TT/3B DATED. 20th Oct 2015) and Aminu Kano Teaching Hospital, Kano state Nigeria (AKTH/MAC/SUB/12A/P-3/VI/1600 15th Sep 2015).

\section{Study Sites}

Three tertiary hospitals that served as referral centers had facilities to admit patients in Kano metropolis of North-western Nigeria were selected for this study.

The hospitals were as follows:

1. Aminu Kano Teaching Hospital (AKTH). Federal Teaching Hospitals and referral hospital was receiving a patient from another Northern state such as Kaduna, Katsina, and Jigawa.

2. Murtala Muhammad Specialist Hospital (MMSH) Kano state. Government Tertiary Hospital Kano State.

3. Muhammad Abdullahi Wase Specialist Hospital (MAWSH). Also, state Government Tertiary Hospital Kano State.

\section{Study Design}

It was a biphasic cross-sectional hospital-based study that involved a retrospective review of previously generated information and prospective assessment of health records.

Consents forms were admitted in all the hospitals as mentioned above, meeting the inclusion criteria. The patients or guardians of the patients interviewed to obtain demographic data. 


\section{Target Population}

All Prolonged hospital patients who spent 14 days and above, aged 18 years and above admitted in the medical, surgical, accident/ orthopedic, and isolation wards, were only considered.

\section{Data Collection}

Medical history and socio-demographic data obtained from caregiver and case files review were used. Data were collected using a wellstructured questionnaire from patients admitted with prolonging the hospital stay. The prolonged hospital stay was assessed using the method described by Tobi et al., (2014), using a retrospective analysis of health records. After procurement endorsement for the study from the hospital management of all the study hospitals (AKTH, MAWSH, and MMSH), Hospital record of the patients admitted during the study month of July 2017, were assessed to determine the length of hospital stay by the patients. The prolonged hospital stay was calculated from the day of admission to the day of discharge of the patient. Prolonge hospital stay is defined as an inpatient stay that exceeds the expected Lenth of Stay (LOS) for a specific procedure (Siu et al., 2018). We considered a prolonged stay longer than 14 days, according to Tobi et al.,. 2015.

\section{Samples Collection}

A total of 401 non reproduced clinical samples collected from patients whose admission is for $\geq 14$ days and aged $\geq 18$ years in the three study sites. Examples include wound swabs, urine samples, urine catheters, and nasal intubation. Wound, urine, urine catheters, and nasal intubation samples were cultured on blood agar, chocolate agar, and MacConkey agar. In contrast, urine and urine catheters samples are cultured on cysteine, lactose electrolyte deficient (CLED), and MacConkey agar. All the plates remained incubated at $370 \mathrm{C}$ for $18-24$ hours.

\section{Bacterial Isolation and Identification}

Plates were examined for growth after 18-24 hour incubation at 370C. MacConkey agar plates were tested for lactose or non-lactose fermentation, while blood and chocolate agar plates were considered for complete or partial hemolysis. All the isolated organisms were Gram stain, and the Biochemical test was carried out according to Cheesbrough (2010).

\section{Data Analysis}

Descriptive statistics were applied to state the prevalence rate and cumulative prevalence of HCAIs. A chi-square test was used to compare total patients admitted and those with the prolonged hospital stay. The level of significance

\section{RESULTS}

Hospital's health records of patients admitted in Medical, Surgical, and Accident/Orthopaedic wards in July 2017 from three studied hospitals reviewed. Records showed that 994 patients admitted in which 401(40.34\%) patients had prolonged hospital stays. The prevalence of prolonged hospital stay, according to hospitals, showed that MMSH had the highest prevalence of $140(50.54 \%)$ of prolonged hospital stay while MAWSH had the least 140(50.54\%) prolonged hospital stay. The statistical comparisons between the studied hospitals using Chi-square tests showed a statistical difference ( $p \leq$ 0.0001 ) between the three hospitals (Table 1 ).

A total of 401 admitted patients whose consent and spend $\geq 14$ days and of $\geq 18$ years in all the three study sites participated in this study. Patients of age group $49-58$ years have the highest number of admitted patients of 111 $(27.7 \%)$ followed by age group $59-68$ years 80 $(20.0 \%)$, and the least was observed in age groups $18-28 y e a r s w i t h ~ 37$ (9.2\%) respectively. According to gender, female patients in the study were found to be the highest Two hundred and one (50.1\%)than male patients (Table 2).

A total of 138 samples were found to be positive in this study. MMSH and MAWSH have higher isolated organisms of 58 (4I.4\%) and(36.0\%), respectively. The overall highest positivity 28 $(20.3 \%)$ obtained in the age group $49-58$ years following by $26(18.8 \%)$ in the age group $49-58$ years. The least was observed in the age group $18-28$ years with 14(10.2\%), respectively (Table 3 ).

A total of 401 patients were screened out of which $138(34.4 \%)$ were positive. The distribution of organisms according to the site of infections showed that Wound/pus surgical site infections had the highest prevalence $48(34.8 \%)$, followed by urinary tract infections $43(31.2 \%)$, catheter Associated UTIs 30(21.7\%) and least infections recorded from nasal intubation 17(12.3\%). Among organisms isolated, $E$. coli was the most frequently identified organism 36(26.1\%), followed by Proteus spp 23(16.7\%), and the least was Acinetobacter $14(10.1 \%)$. Streptococcus pyogenes $11(8 \%)$ (Table 4). 
BAJOPAS Volume 12 Number 2, December, 2019

Table 1: Prevalence of prolonged hospital stay in three Hospitals Kano State, Nigeria

\begin{tabular}{|c|c|c|c|c|c|}
\hline Hospital & $\begin{array}{l}\text { No. } \\
\text { examined }\end{array}$ & $\begin{array}{c}\text { Prolonged } \\
\text { hospital stay n (\%) }\end{array}$ & $95 \% \mathrm{CI}$ & $\begin{array}{c}x^{2} \\
\text { value }\end{array}$ & $\begin{array}{c}\mathrm{x}^{2} \\
\text { value }\end{array}$ \\
\hline AKTH & 506 & $200(39.53)$ & $\begin{array}{l}(0.3533- \\
0.4384)\end{array}$ & & \\
\hline MAWSH & 211 & $61(28.91)$ & $\begin{array}{l}(0.2309- \\
0.3530)\end{array}$ & 23.571 & $\leq 0.0001^{*}$ \\
\hline $\mathrm{MMSH}$ & 277 & $140(50.54)$ & $\begin{array}{l}(0.4466- \\
0.5658)\end{array}$ & & \\
\hline Total & 994 & $401(40.34)$ & $\begin{array}{l}(0.3727- \\
0.4342)\end{array}$ & & \\
\hline
\end{tabular}

Key:AKTH: Aminu Kano Teaching Hospital, MAWSH: Muhammed Abdullahi Wase Specialist Hospital Kano, MMSH: Murtala Muhammed Specialist Hospital Kano.

Table 2: Demographical Distribution of the Participants in the Study (N 401)

\begin{tabular}{|c|c|c|c|c|}
\hline \multirow[t]{2}{*}{ Variables } & \multicolumn{3}{|c|}{ Study Sites } & \multirow{2}{*}{$\begin{array}{l}\text { Total (\%) } \\
\text { All Sites } \\
(\mathrm{n}=401) \\
\mathrm{n}(\%)\end{array}$} \\
\hline & $\begin{array}{l}\text { AKTH } \\
(n=200) \\
n(\%)\end{array}$ & $\begin{array}{l}\text { MAWSH } \\
(n=61) \\
n(\%)\end{array}$ & $\begin{array}{l}\text { MMSH } \\
(n=140) \\
n(\%)\end{array}$ & \\
\hline \multicolumn{5}{|c|}{ Age (Years) } \\
\hline $18-28$ & $10(5.0)$ & $2(3.3)$ & $25(17.9)$ & $37(9.2)$ \\
\hline $29-38$ & $15(7.5)$ & $9(14.8)$ & $19(13.6)$ & 43 (10.7) \\
\hline $39-48$ & $41(20.5)$ & $7(11.5)$ & $27(19.3)$ & 75 (18.7) \\
\hline $49-58$ & $62(31.0)$ & $27(44.3)$ & $22(15.7)$ & $111(27.7)$ \\
\hline $59-68$ & $41(20.5)$ & $9(14.3)$ & $30(21.4)$ & $80(20.0)$ \\
\hline $69-78$ & $31(15.5)$ & $7(11.5)$ & $17(12.1)$ & 55 (13.7) \\
\hline Total & $200(100)$ & $61(100)$ & $140(100)$ & $401(100)$ \\
\hline \multicolumn{5}{|l|}{ Sex } \\
\hline Male & $107(53.5)$ & $30(49.2)$ & $63(45.0)$ & 200 (49.9) \\
\hline Female & $93(46.5)$ & $31(50.8)$ & $77(55.0)$ & $201(50.1)$ \\
\hline Total & $200(100)$ & $61(100)$ & $140(100)$ & $401(100)$ \\
\hline
\end{tabular}

Table 3: Distribution of Positive Isolates Obtained from the Three Study Sites in respect to the Age group of the Subject participants

\begin{tabular}{|c|c|c|c|c|}
\hline \multirow[t]{2}{*}{ Ages (Years) } & \multicolumn{3}{|c|}{ Study Sites } & \multirow{2}{*}{$\begin{array}{l}\text { Total (\%) } \\
\text { All Sites } \\
(\mathrm{n}=401) \\
\mathrm{n}(\%)\end{array}$} \\
\hline & $\begin{array}{l}\text { AKTH } \\
(n=58) \\
n(\%)\end{array}$ & $\begin{array}{l}\text { MAWSH } \\
(n=22) \\
n(\%)\end{array}$ & $\begin{array}{l}\text { MMSH } \\
(n=58) \\
n(\%)\end{array}$ & \\
\hline $18-28$ & $2(3.4)$ & $2(9.0)$ & $10(17.2)$ & $14(10.2)$ \\
\hline $29-38$ & $9(15.5)$ & $6(27.2)$ & $10(17.2)$ & $25(18.1)$ \\
\hline $39-48$ & $13(22.4)$ & $3(13.6)$ & $12(20.7)$ & $28(20.3)$ \\
\hline $49-58$ & $17(29.3)$ & $3(13.6)$ & $6(10.3)$ & $26(18.8)$ \\
\hline $59-68$ & $10(17.24)$ & $3(13.6)$ & $10(17.2)$ & $23(16.7)$ \\
\hline $69-78$ & $7(12.1)$ & $5(22.7)$ & $10(17.2)$ & $22(15.9)$ \\
\hline Total & $58(29.0)$ & $22(36.0)$ & $58(41.4)$ & $138(100.0)$ \\
\hline
\end{tabular}

Table 4: Organisms isolated from various health care associated infections sample in three Hospital Kano State, Nigeria

\begin{tabular}{|c|c|c|c|c|c|c|}
\hline \multirow{2}{*}{ Organisms Isolated } & \multicolumn{5}{|c|}{ Types of patients' samples analyzed } & \multirow{2}{*}{$\begin{array}{l}\text { Total } \\
\text { Isolates } \\
\text { n (\%) }\end{array}$} \\
\hline & $\begin{array}{l}\text { Wound } \\
\text { n (\%) }\end{array}$ & $\begin{array}{l}\text { Urine } \\
\text { n (\%) }\end{array}$ & $\begin{array}{l}\text { Urine } \\
\text { Catheter } \\
\text { n (\%) }\end{array}$ & $\begin{array}{l}\text { Nasal } \\
\text { Intubation } \\
(\%) \\
\end{array}$ & $\mathbf{n}$ & \\
\hline Acinetobacter species & $4(8.3)$ & $5(11.6)$ & $4(13.3)$ & $1(5.9)$ & & $14(10.2)$ \\
\hline Klebsiella species & $2(4.2)$ & $10(23.3)$ & $6(20.0)$ & $3(17.7)$ & & $21(15.2)$ \\
\hline Escherichia coli & $11(22.9)$ & $17(39.5)$ & $8(26.7)$ & $0(0.0)$ & & $36(26.1)$ \\
\hline Proteus species & $5(10.4)$ & $4(9.3)$ & $6(20.0)$ & $8(47.1)$ & & $23(16.7)$ \\
\hline Staphylococcus aureus & $10(20.8)$ & $5(11.6)$ & $3(10.0)$ & $2(11.8)$ & & $20(14.5)$ \\
\hline Streptococcus pyogenes & $6(12.5)$ & $0(0.0)$ & $2(6.7)$ & $3(16.7)$ & & $11(8.0)$ \\
\hline Pseudomonas species & $10(20.8)$ & $2(4.7)$ & $1(3.3)$ & $0(0.0)$ & & $13(9.4)$ \\
\hline Total isolates/sample & $48(34.8)$ & $43(31.2)$ & $30(21.7)$ & $17(12.3)$ & & $138(100)$ \\
\hline
\end{tabular}


BAJOPAS Volume 12 Number 2, December, 2019 DISCUSSION

This study investigated the length of hospital stay, and nosocomial infection in patients admitted to general surgery, medical and accident/Orthopedic wards. Prolonging hospital stay in three study areas, Kano state Nigeria was 994/401 (40.34\%). The Prevalence of prolonging hospital admission in three hospitals was AKTH (39.53\%), MAWSH (28.91\%), and MMSH (50.50\%). The Prevalence was higher than previous study which reported $14.56 \%$ in the Intensive care unit hospital in Turkey (Banu et al., 2018). This study took place in two tertiary government hospitals and one private Teaching hospitals in Kano metropolis. Generally, Nigeria, and indeed Kano city with a population of over 25 million people, have limited resources for health to meet the booming community of healthcare seekers. Age serves as an essential factor associated with prolonged hospital stays, and the occurrence of hospitalacquired infections. Age group 49 - 58 years were more vulnerable to have an infection. A high prevalence of NI was obtained from patients age group $39-48$ years, $20.3 \%$. Elderly aged people are more vulnerable to this problem of having exposed to so many infections pathogens that can result from prolonged hospitalization (Zang et al., 2019). The use of invasive procedures could raise the risk of opportunistic pathogens. Millar et al. (2019) reported in their study said that age was statistically significant risk factor for the occurrence of nosocomial infection that can results in prolonged hospital stays. The female participants have slightly higher percentage of $50.1 \%$ than the male participants; the reason for this is not yet ascertained. Gram-negative isolates were the most common prevalence isolates with rates of $77.5 \%$ and Gram-positive $22.5 \%$ of the total number of isolates. Gramnegative organisms have reported as commonly associated with hospital-acquired infections in previous studies done by (Guo 2019; Samad 2019). The pathogens isolated from surgical site infection example (Staphylococcus aureus, Pseudomonas spp, and $E$. coll) were severally reported as the principal causative agent of nosocomial infections (Dinda, 2014; Egwuh, 2016 and Nwobu 2004).

These results are in agreement with the present results; the Prevalence of $34.8 \%$ obtained in the study is within the global prevalence range of $2.5 \%$ to $41.0 \%$ (Mbim et al., 2016). This finding (34.4\%) broadly support the work of other studies done in Africa but reported higher than Prevalence from Nigeria (2.6\%), Morocco (10.3\%) and Ethiopian (19.41\%) (Ige et al., REFERENCES
2011, Razine et al., 2012 and Solomon et al., 2018). The high patient's load could explain this in the three referral hospitals in the study area and overcrowding. On the other hand, the Occurrence of HAI in this study is lower than the reported Prevalence from Addis Ababa (35.8\%) (Endalafer et al., 2011). But Ugandan study reported a low Prevalence of HAIS 15\% (Ogwang et al., 2013). This finding was consistent also with that of Afolabi et al., 2011, who also reported, 34\% prevalence of HCAIS in a Nigerian study. In this study, Prevalence of UTI was found to be (31.2\%) which is relatively lower than $32.2 \%$ ) UTI prevalence reported in the study of Odoki et al., 2019) but low Prevalence was reported (27.24\%) (Nisha et al., 2018). The low Prevalence might be due to patients taking antibiotics before urine culture or infection due to slow-growing organisms or fastidious organisms. The prominent bacterial pathogens from a wound in our study was, $E$. coli, $S$. aureus, and $P$. aeruginosa. This finding broadly supports the work of another study of (Mekonnen et al., 2019) who reported Prevalence of $S$. aureus $36 \%, E$ coli $13 \%$ and $P$. aeruginosa, $9 \%$ in their study. (Alkali et al., (2019) reported $E$ coli and $S$. aureus as predominant isolates causing wound infection, this was in line with several published studies.

Several studies which stated that gram-positive aerobic cocci, mainly, Staphylococci, has been the primary cause of wound infections (Garg et al., 2018; Perim et al., 2015, Bessa et al., 2015). $S$. aureus has been described as the most common bacterial pathogen isolated from several wound samples (Perim et al., 2015 and Bessa et al., 2015).

\section{CONCLUSION AND RECOMMENDATION}

The prevalence of bacterial causing nosocomial infection was $34.4 \%$ in the three hospitals, AKTH (39.53\%), MMSH (50.50\%), and MAWSH (28.91\%). The Prevalence of prolonged hospital stay in three hospitals respectively were AKTH (39.53\%), MAWSH (28.91\%), and MMSH $(50.50 \%)$. This study also showed that Gramnegative bacterial were the predominant isolates that cause nosocomial infection among prolonged hospital stays patients. Hospital management should not just keep patients in their hospitals for a long period but should report such group to the Ministries of health so that help can come from Government. Surveillance on risk factors and bacterial pathogens impacting on the duration of hospital stay should be mounted to ensure that these pathogens accurately managed to reduce the length of hospital stay by patients. 
BAJOPAS Volume 12 Number 2, December, 2019

Afolabi O.T., Onipede A.O., Omotayo S.K(2011). Hospital acquired infection in Obafemi Awolowo University Teaching Hospital, Ile-Ife, Southwest, Nigeria: a ten year review (2000-2009) Sierra Leone J. Biomed. Res.3(2):110-115.

Alormenyo, N. M. (2019). Trends and Determinants of Nosocomial Infection among Hospitalised Patients at Koforidua Regional Hospital(Doctoral dissertation, University of Ghana)..

BanuÇevik: FatihDoğuGeyik (2018)Prolonged stay in intensive care unit: Retrospective analysis of predisposing factors and outcome; Journal of Turkey Societyof Intensive Care DOI: 10.4274/tybd.galenos.58561.Care Med; 27:1319-24.

BessaLJ.Fazil P,DI Cellini I, Bacterial isolates from infected wounds and their antibiotic susceptibility pattern; some remarks about wound infection. Int wound $\mathrm{j}, 12(1) ; 47-52$

Chandra PN, Milind $\mathrm{K}$. Lapses in measures recommended for preventing hospitalacquired infection. Journal of Hospital Infectious. 2001;47:218-22.

Cheesbrough, M. (2010). District Laboratory Practice in Tropical Countries. Cambridge university press, 2:132-142, $382-416$.

Dinda, V. O. (2014). Surveillance of Surgical Site Infections at The Aga Khan University Hospital, Nairobi (Doctoral dissertation).

Egwuh, P. N. (2016). Asymptomatic Bacteriuria In Type 2 Diabetic Women Attending The General Out-Patient Clinic Of Nnamdi Azikiwe University Teaching Hospital, Nnewi, Nigeria. Faculty of Family Medicine.,

Endalafer N, Gebre-Selassie S, Kotiso B(2011). Nosocomial bacterial infections in tertiary hospital in Ethiopia. J Infect Prev. 12(1):38-43.

Garg, S., Bloch, N., Potter, M., Quick, H., Palmer, C., Michael, N., ... \& Erickson, M. (2018). Topical vancomycin in pediatric spine surgery does not reduce surgical site infection: a retrospective cohort study. Spine deformity, 6(5), 523-528.

Haque, M., Sartelli, M., McKimm, J., \& Bakar, M. A. (2018). Health care-associated infections-an overview. Infection and drug resistance, 11, 2321.).

Ige OK, Adesanmi AA, Asuzu MC(2011). Hospital-acquired infections in $a$ Nigerian tertiary health facility: an audit of surveillance reports. Niger Med J.52(4):239-43.

Iliyasu, G., Dayyab, F. M., Habib, Z. G., Tiamiyu, A. B., Abubakar, S., Mijinyawa, M. S., \& Habib, A. G. (2016). Knowledge and practices of infection control among healthcare workers in a Tertiary Referral Center in North-Western Nigeria. Annals of African medicine, 15(1), 34

Liu, C., \& Guo, J. (2019). Hypervirulent Klebsiella pneumoniae (hypermucoviscous and aerobactin positive) infection over 6 years in the elderly in China: antimicrobial resistance patterns, molecular epidemiology and risk factor. Annals of clinical microbiology and antimicrobials, 18(1), 4.

Marriott, D. J., \& Morrissey, C. O. (2019). Common Infections Following Lung Transplantation. In Essentials in Lung Transplantation (pp. 173-219). Springer, Cham

Khan, H. A., Baig, F. K., \& Mehboob, R. (2017). Nosocomial infections: epidemiology, prevention, control and surveillance. Asian Pacific Journal of Tropical Biomedicine.

https://doi.org/10.1016/j.apjtb.2017.01. 019

Tobi, K. U., \& Amadasun, F. E. (2015). Prolonged stay in the Intensive Care Unit of a tertiary hospital in Nigeria: Predisposing factors and outcome. African Journal of Medical and Health Sciences, 14(1), 56-60.

Odoki Martin, Adamu_Almustapha Aliero, Julius_Tibyangye, Josephat_Nyaba yo

Maniga, Eddie_Wampande, Charles_Drag o Kato, Ezera_Agwu, and Joel_Bazira (2019)Prevalence of Bacterial Urinary Tract Infections and Associated Factors among Patients Attending Hospitals in Bushenyi District, Uganda; International Journal of Microbiology Volume, Article ID 4246780, 8 pages

Millar, M. (2019). Device-associated infections. Tutorial Topics in Infection for the Combined Infection Training Programme, 286.

National Bureau of Statistics (NBS) (2018). The latest population figures from national bureau of statistics you need to see; Business insider by pulse. Retrieved on $5^{\text {th }}$ January, 2018.

Ogwang M., Paramatti D., Molteni T(2013). Prevalence of hospital-associated infections can be decreased effectively 
BAJOPAS Volume 12 Number 2, December, 2019

in developing countries. J. Hosp. Infect.84(2):138-

142. [PubMed] [Google Scholar])

Perim , MM, Borges JC, Caleste SRC, Orsolin, EF. Mendes RR, Mendes GO, Ferreira RL,.Carreiro SC, Pranchevicius MCS (2015). Aerobic bacterial profile and antibiotic resistance in patients with diabetic foot infection, Rev Soc, Bras Med Tro.48(5); 546-554

Pitted .Haque, M., Sartelli, M., McKimm, J., \& Bakar, M. A. (2011). Health careassociated infections-an overview. Infection and drug resistance, 11, 2321

Prashanth, S. (2019). A Study on Causes and Management of Enterocutaneous Fistula (Doctoral dissertation, Coimbatore Medical College, Coimbatore)..

Razine R, Azzouzi A, Barkat A,(2012) et al. Prevalence of hospital-acquired infections in the university medical center of Rabat. Morocco Int Arch Med.5(1):26.

Samad, A., Asghar, M., Naeem, M., Rehman, N., Asghar, N., Haroon, M., ... \& Ali, G. (2019). Identification of pathogenic bacteria isolated from tissues, bones infections and their antibiotic susceptibility pattern at Khyber Teaching Hospital, Peshawar. Pak J Surg, 35(1), 21-25).

Solomon Ali, Melkamu Birhane, Sisay Bekele, Gebre Kibru, Lule Teshager, Yonas Yilma, Yesuf Ahmed, Netsanet Fentahun, Henok Assefa, Mulatu
Gashaw \& Esayas

Kebede(Gudina(2018)Healthcare associated infection and its risk factors among patients admitted to a tertiary hospital in Ethiopia: longitudinal study;Antimicrobial Resistance \& Infection Controlvolume 7, Article number: $2 \mathrm{C}$

Tobi KU, Amadasun FE (2015). Prolonged stay in the Intensive Care Unit of a tertiary hospital in Nigeria : Predisposing factors and outcome. African Journal of Medical Health Science 14:56-60.

Wang, W., Zhu, S., He, Q., Zhang, R., Kang, Y., Wang, M., ... \& Sun, X. (2019). Developing a Registry of HealthcareAssociated Infections at Intensive Care Units in West China: Study Rationale and Patient Characteristics. Clinical Epidemiology, 11, 1035.

Wohrley, J. D., \& Bartlett, A. H. (2019). The Role of the Environment and Colonization in Healthcare-Associated Infections. In Healthcare-Associated Infections in Children (pp. 17-36). Springer, Cham

World Health Organization, Prevention of hospital-acquired infections: a practical guide World Health Organization, Geneva (2015) 2002. (Online) Available:http://www.who.int/csr/resour ces/publications/whocdscsreph200212.p df [Accessed on 8th February, 2015]

World Health Organization(2016). Prevention of hospital-acquired infections. A practical guide. 2nd ed [Internet]. Geneva: World Health Organization. c2002 [cited 2017 Nov 13]. 